\title{
The DDAH/NOS pathway in human prostatic cancer cell lines: Antiangiogenic effect of L-NAME
}

\author{
LUCA VANELLA $^{1}$, CLAUDIA DI GIACOMO ${ }^{1}$, ROSARIA ACQUAVIVA ${ }^{1}$, ROSA SANTANGELO $^{1}$, \\ VENERA CARDILE ${ }^{2}$, IGNAZIO BARBAGALLO ${ }^{1}$, NADER G. ABRAHAM $^{3}$ and VALERIA SORRENTI ${ }^{1}$ \\ ${ }^{1}$ Dipartimento di Scienze del Farmaco, Sezione di Biochimica, ${ }^{2}$ Dipartimento di Scienze Fisiologiche, Università di \\ Catania, I-95125 Catania, Italy; ${ }^{3}$ Department of Physiology and Pharmacology, University of Toledo, OH, USA
}

Received May 3, 2011; Accepted June 6, 2011

DOI: $10.3892 /$ ijo.2011.1107

\begin{abstract}
Benign prostate hypertrophy (BPH) and prostate cancer (PC) are prostate chronic diseases that require a long period for development from a small lesion to clinical manifestation. PC is the most common cancer in men in Europe and the Americas. Tumor growth and metastasis depend upon the development of neovasculature around the tumor. This process, called angiogenesis, may be regulated by NO, and thus modulation of NO production could play an important role in tumor progression. Recent studies report the involvement of DDAH, an enzyme which metabolizes the endogenous NOS inhibitor ADMA, in the development of tumor vasculature. The aim of the present study was to verify the involvement of the DDAH/ NOS pathway in the progression of prostate cancer. The effect of the NOS inhibitor L-NAME was evaluated in the human prostate cancer cell line LnCap and in BPH-1 cells which represent benign prostatic hypertrophy. Higher DDAH-2, eNOS, iNOS and VEGF expression was found in LnCap cells compared to BPH-1 cells. L-NAME treatment of LnCap cells resulted in a reduction in VEGF, iNOS and eNOS expression. VEGF, iNOS and eNOS inhibition is a promising approach for targeting tumor vasculature and certain NOS inhibitors could potentially serve as experimental agents for treatment of certain chemoresistant tumors, including prostate tumors. Moreover, since in our experimental conditions L-NAME was unable to reduce DDAH activity and expression, it is plausible to hypothesize the development of a targeted polypharmacological approach by developing dual and specific inhibitors of DDAH and NOS to better control NO biosynthesis.
\end{abstract}

\section{Introduction}

Benign prostate hypertrophy (BPH) and prostate cancer (PC) are prostate chronic diseases that require a long period for

Correspondence to: Professor Valeria Sorrenti, Dipartimento di Scienze del Farmaco, Sezione di Biochimica, Università di Catania, v.le A. Doria 6, I-95125 Catania, Italy

E-mail: sorrenti@unict.it

Key words: DDAH, NOS, VEGF, L-NAME, angiogenesis, prostate cancer development from a small lesion to clinical manifestation. PC is the second leading cause of death in men of Western world (1) (American Cancer Society 2007 Prostate Cancer Statisticshttp://www.cancer.org; American Society of Clinical Oncology Prostate Cancer Statistics- http://www.cancer.net/prostate).

Despite significant improvements in local and systemic therapies, most deaths from prostate cancer are due to metastasis which resist conventional therapies (2-4). Therefore, novel therapeutic strategies targeting specific molecular markers are being pursued to allow early detection and cure.

Tumor growth and metastasis depend upon the development of a neovasculature around the tumor (5-9). This process, called angiogenesis, is critical to tumorigenicity and metastasis (10). Similarly to carcinogenesis, angiogenesis is a multistep process, regulated by a balance between stimulatory and inhibitory factors released by the tumor and its microenvironment (7,11-17).

Angiogenesis facilitates tumor growth through a series of steps including dissociation of endothelial cells (EC) from adjacent perycites, remodelling of extracellular matrix, proliferation and migration of EC and capillary differentiation.

Nitric oxide (NO) is a signalling molecule produced by three isoforms of nitric oxide synthases (neuronal NOS, endothelial NOS and inducible NOS); it mediates a variety of actions such as vasodilatation, neurotransmission, host defence against bacteria and tumor cells $(18,19)$.

Strong evidence suggests that NO is a regulator of angiogenesis $(20,21)$, which enhances vascular permeability, induces extracellular matrix degradation, endothelial cell proliferation and migration (22-24) and stimulates the expression of vascular growth factor (VEGF) $(25,26)$. Increased iNOS expression and NOproduction in BPHand inhigh grade PCoccur when compared to normal tissue (27). Prostate cancer cells express lower levels of antioxidant enzymes than BPH cells and compared to normal prostatic cells, activity of antioxidant enzymes is decreased in BPH cells $(28,29)$. Although conflicting data have been reported, an overwhelming amount of clinical and experimental evidence suggested a positive association between NO production and tumor progression (30-39). Modulation of NO production may therefore play an important role in regulation of angiogenesis and consequently in tumor progression. Overexpression of dimethylarginine dimethylaminohydrolase (DDAH), enzyme which metabolizes the endogenous NOS inhibitor asymmetric 
dimethylarginine (ADMA), reduces tissue ADMA levels and enhances angiogenesis (40).

The involvement of DDAH in cerebral tumor growth and the development of tumor vasculature has been reported (41). Two isoforms of DDAH have been identified: DDAH-1 and DDAH-2. Although there is some overlapping between the sites of expressions of DDAH-1 and nNOS (neuronal NOS) and between DDAH-2 and eNOS (endothelial NOS), it is now evident that both DDAHs are widely expressed and not confined to NOS expressing cells or tissues (42). Both isoforms have been identified in the prostate tissue, but the expression of DDAH-2 isoform appears more abundant (43).

In order to verify the involvement of DDAH/NOS pathway in the progression of prostate cancer, two different cell lines were used in the present study: BPH-1 cells which represent benign prostatic hypertrophy and LnCap, which are a model of human prostatic carcinoma $(44,45)$. In addition, the effect of the NOS inhibitor $N^{\mathrm{G}}$-nitro-L-arginine methyl ester (L-NAME), which is not degraded by DDAH (40), was examined.

\section{Materials and methods}

Cell culture conditions. Human prostate BPH-1 cells were purchased from Deutsche Sammlung Von Mikroorganism Und Zellkulturen-GmbH (DSMZ-GmbH) and grown in $80 \%$ RPMI-1640 medium supplemented with $20 \%$ fetal bovine serum $(\mathrm{FBS})$ and $20 \mathrm{ng} / \mathrm{ml}$ testosterone, $5 \mu \mathrm{g} / \mathrm{ml}$ sodium selenite, $5 \mu \mathrm{g} / \mathrm{ml}$ insulin and a trace elements mix. Human prostate cancer LnCap cells were purchased from American Type Culture Collection (Manassas, VA) and grown in RPMI-1640 medium supplemented with $10 \%$ fetal bovine serum (FBS), $0.1 \%$ streptomycin-penicillin, $1 \%$ L-glutamine, $1 \%$ sodium pyruvate and $1 \%$ glucose. Cells were incubated at $37^{\circ} \mathrm{C}$ in a $5 \%$ $\mathrm{CO}_{2}$ humidified atmosphere and maintained at subconfluency by passaging with trypsin-EDTA (Gibco).

Cell viability. To monitor cell viability, BPH-1 and LnCap cells were seeded $2 \times 10^{5}$ cells per well in a 96-well, flat-bottomed $200 \mu \mathrm{l}$ microplate. Cells were incubated at $37^{\circ} \mathrm{C}$ in a $5 \% \mathrm{CO}_{2}$ humidified atmosphere and cultured for either 24 or $72 \mathrm{~h}$, in the presence and absence of different concentrations of L-NAME (0.1-1 mM). Four hours before the end of treatment, $20 \mu \mathrm{l}$ of $0.5 \%$ 3-(4,5-Dimethylthiazol-2-yl)-2,5-diphenyltetrazolium bromide (MTT) in phosphate buffered saline (PBS) were added to each microwell. After incubation with the reagent, the supernatant was removed and replaced with $100 \mu \mathrm{l}$ DMSO. The amount of formazan produced is proportional to the number of viable cells present. The optical density was measured using a microplate spectrophotometer reader (Thermo Labsystems Multiskan) at $\lambda=570 \mathrm{~nm}$. Results are expressed as the percentage of formazan produced in treated cells with respect to untreated cells.

Cell count. Cell count was performed on $100 \mu \mathrm{l}$ of cell suspension using a Burker counting chamber divided into 16 fields of $1 \mathrm{~mm}^{2}$. Sedimented cells present in 4 fields were counted. Arithmetical mean $\times 10^{4}$ represents the number of cells $/ \mathrm{ml}$ of medium.

$L D H$ release. Lactic dehydrogenase (LDH) activity was measured spectrophotometrically in the culture medium and cell lysates by analyzing the decrease in NADH absorbance at $\lambda=340 \mathrm{~nm}$ during the pyruvate-lactate transformation, as previously reported $(46,47)$. Cells were lysed with $50 \mathrm{mM}$ Tris- $\mathrm{HCl}$ and $20 \mathrm{mM}$ EDTA pH 7.4 plus $0.5 \%$ sodium dodecyl sulfate, further disrupted by sonication and centrifuged at $13,000 \mathrm{~g}$ for $15 \mathrm{~min}$. The assay mixture ( $1 \mathrm{ml}$ final volume) for the enzymatic analysis contained $33 \mu \mathrm{l}$ of sample (5-10 $\mu \mathrm{g}$ of protein) in $48 \mathrm{mM}$ PBS pH 7.5 plus $1 \mathrm{mM}$ pyruvate and $0.2 \mathrm{mM}$ NADH. The $\mathrm{LDH}$ released was calculated as percentage of the total amount, considered as the sum of the enzymatic activity present in the cell lysate and that in the culture medium. The optical density was measured using a Hitachi U-2000 dual beam spectrophotometer (Hitachi, Tokyo, Japan).

Western blotting. BPH-1 and LnCap cells cultured for $24 \mathrm{~h}$, in both the presence and absence of 0.1-1 mM L-NAME, were suspended in $25 \mathrm{mM}$ Tris buffer, $\mathrm{pH} 8.5$, containing $100 \mathrm{mM} \mathrm{NaCl}$ (Sigma-Aldrich, St. Louis, MO, USA), 7 mM mercaptoethanol (Merck KGaA, Darmstadt, Germany) and a protease inhibitor cocktail (1:1000) (Sigma-Aldrich) and then sonicated for 3 cycles of $5 \mathrm{sec}$. The whole lysate was collected to evaluate DDAH-2, VEGF, eNOS and i-NOS expressions by Western blot analysis. Briefly, $50 \mu \mathrm{g}$ of lysate was loaded in a 10\% SDS-PAGE and transferred to a nitrocellulose membrane (Bio-Rad Laboratories, Hercules, CA, USA). The membranes were blocked with $3 \%$ fat-free milk in $10 \mathrm{mM}$ Tris- $\mathrm{HCl}(\mathrm{pH} 7.4), 150 \mathrm{mM} \mathrm{NaCl}$ and $0.05 \%$ TBST buffer, at $4^{\circ} \mathrm{C}$ for $2 \mathrm{~h}$ and then incubated with polyclonal anti-DDAH-2 (Calbiochem EMD Biosciences, Inc., Darmstadt, Germany), monoclonal anti-eNOS (Sigma-Aldrich), anti-VEGF (Santa Cruz Biotechnologies, Inc., Santa Cruz, CA, USA) and anti-iNOS (Santa Cruz Biotechnologies) antibodies overnight at room temperature, with constant shaking. The same membranes were used for blotting with anti- $\beta$-actin (Santa Cruz Biotechnologies) antibody as an internal loading control. The filters were then washed and probed with horseradish peroxidase-conjugated donkey secondary anti-mouse, anti-rabbit and anti-goat IgG (Amersham Biosciences, Piscataway, NJ, USA) at a dilution of 1:5000. Chemiluminescence detection was performed with the ECL plus detection kit (Amersham) according to the manufacturer's instructions. Western blot analyses were quantified by densitometric analysis performed after normalization with $\beta$-actin. Results were expressed as arbitrary units (AU).

DDAH enzyme activity assay. Cell lysates were centrifuged at $2000 \mathrm{~g}$ for $45 \mathrm{~min}$ at $4^{\circ} \mathrm{C}$ and supernatants were collected for evaluating DDAH enzymatic activity and protein content by the Lowry et al assay (48). DDAH activity was assayed by determining L-citrulline formation in 96-well microtiter plate (49). One unit of enzyme activity was defined as the amount of enzyme catalyzing the formation of $1 \mu \mathrm{mol} \mathrm{L}$-citrulline $/ \mathrm{min}$ at $37^{\circ} \mathrm{C}$.

$\mathrm{NO}_{2}{ }^{-} / \mathrm{NO}_{3}{ }^{-}$quantification. Nitrite, the stable metabolite of $\mathrm{NO}$, was measured colorimetrically via Griess's reaction. Based on results regarding cell viability, for $\mathrm{NO}_{2}{ }^{-} / \mathrm{NO}_{3}{ }^{-}$determination, cells were cultured in presence or absence of 0.1-1 mM L-NAME for $24 \mathrm{~h}$, after which the media were removed and used as below described.

Aliquots of cell culture medium $(100 \mu 1)$ were preincubated for $30 \mathrm{~min}$ at room temperature with $50 \mu \mathrm{M}$ NADPH (SigmaAldrich) and $24 \mathrm{mU}$ of nitrate reductase (Roche Diagnostics 


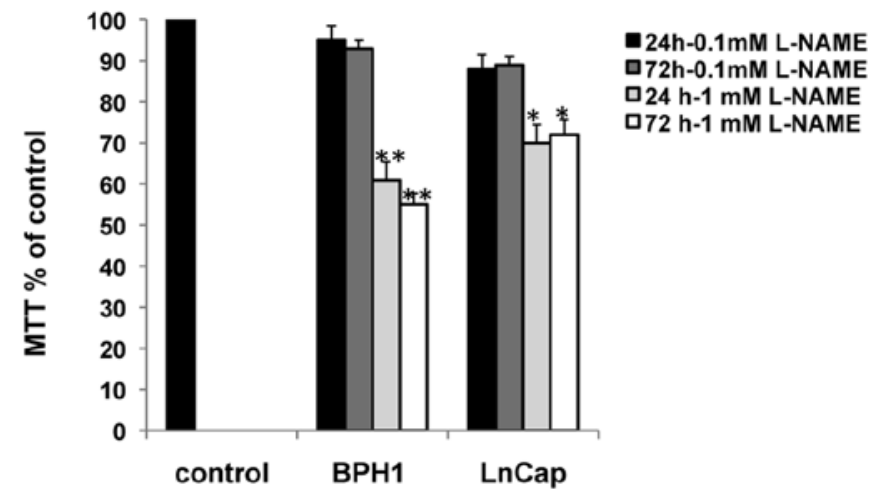

Figure 1. Cell viability in cultured BPH-1 and LnCap cells after treatment with different L-NAME (0.1-1 mM) concentrations for 24 and $72 \mathrm{~h}$. Values are the mean \pm SD of 4 experiments in triplicate. Significance of L-NAME $(0.1-1 \mathrm{mM})$ versus BPH-1 control; ** $p<0.005$. Significance of L-NAME $(0.1-1 \mathrm{mM})$ versus LnCap control; ${ }^{*} \mathrm{p}<0.05$.

Gmbh, Mannheim, Germany). Samples were then treated with $0.2 \mathrm{U}$ of lactate dehydrogenase (Roche Diagnostics Gmbh) and $0.5 \mu \mathrm{mol}$ of sodium pyruvate for $10 \mathrm{~min}$. The coloration was developed adding Griess reagent (Merck KGaA) (1:1, v/v). Finally, after $10 \mathrm{~min}$ at room temperature, absorbance was recorded using a 96-well plate microtiter (Thermo Labsystems Multiskan) at $\lambda=540 \mathrm{~nm}$. Nitrite levels were determined using a standard curve and expressed as nmoles of $\mathrm{NO}_{2}{ }^{-} / \mathrm{NO}_{3}{ }^{-} / 1 \times 10^{6}$ cells.

Statistical analyses. The data are presented as means \pm SD for 4 experiments in triplicate. One-way variance analysis and Student's t-test were used where appropriate; $\mathrm{p}<0.05$ was regarded as significant.

\section{Results}

Effect of L-NAME on BPH-1 and LnCap cell proliferation. Cell viability, measured as functionality of succinate dehydrogenase, is reported in Fig. 1. The exposition of cell culture to $0.1 \mathrm{mM}$ L-NAME did not modify BPH-1 and LnCap viability after either 24 or $72 \mathrm{~h}$. When BPH1 and LnCap cells were exposed to $1 \mathrm{mM}$ L-NAME, a significant reduction in viability was observed. This effect was less in LnCap cells when compared to BPH-1 cells and was not time-dependent since both 24 and $72 \mathrm{~h}$ of exposure to L-NAME elicited the same 30 or $40 \%$ reduction in cell viability. The growth of BPH-1 and LnCap cell lines was examined by direct cell counting after treatment for $72 \mathrm{~h}$ with L-NAME $(0.1$ and $1 \mathrm{mM}$ ) (Fig. 2). Although the results obtained show a reduction in cell number after $72 \mathrm{~h}$ of exposure to L-NAME, LnCap cells appeared more resistant to L-NAME treatment compared to BPH-1 cells. In fact, a significant cell number reduction was evident only at $1 \mathrm{mM}$ concentration (Fig. 2A). Fig. 2B shows representative images of BPH-1 and LnCap cells cultured in the presence and absence of $1 \mathrm{mM}$ L-NAME and show a significant decrease in cell number. The results of LDH release after exposure to L-NAME are shown in Fig. 3. Twenty-four-hour exposure to $0.1 \mathrm{mM}$ L-NAME did not increase $\mathrm{LDH}$ release in either BPH-1 or LnCap. However both cell types showed increased LDH release, particularly after $72 \mathrm{~h}$ of treatment with $1 \mathrm{mM}$ L-NAME $(\mathrm{p}<0.005)$.
(A)

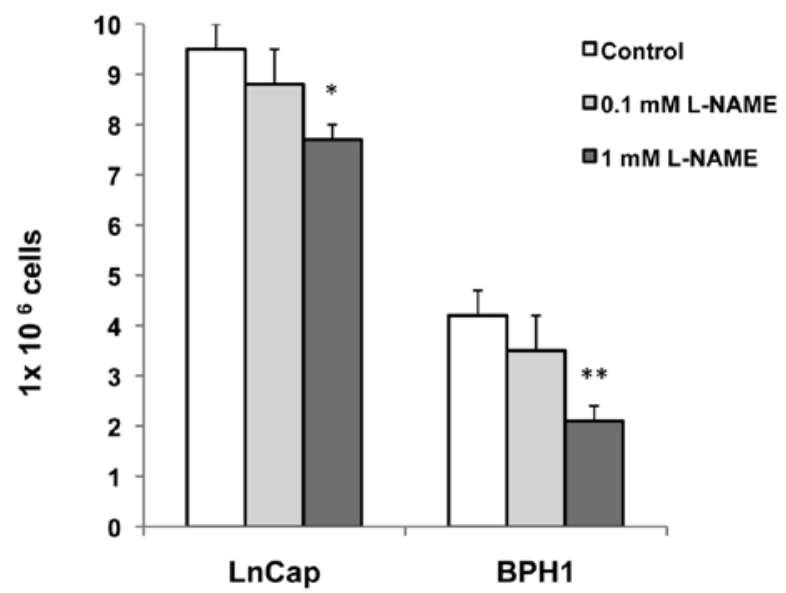

(B)
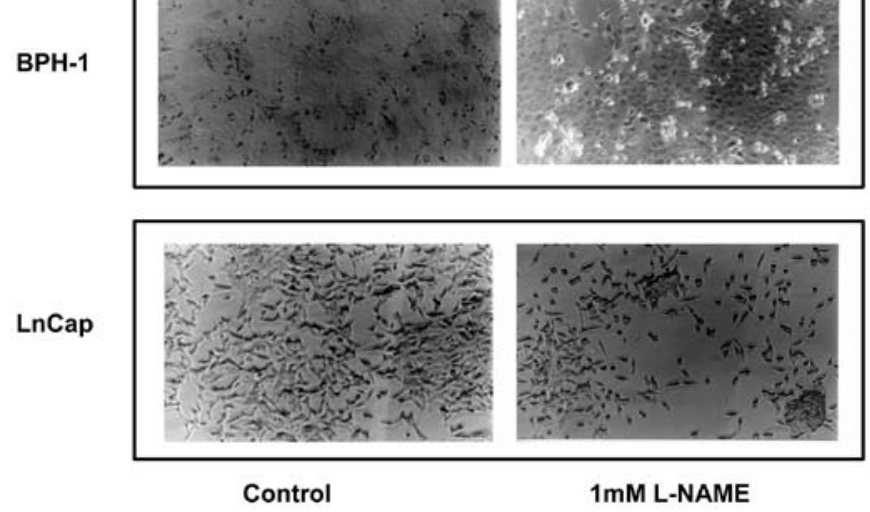

Figure 2. Cell count in BPH-1 and LnCap cells after treatment with different L-NAME (0.1-1 mM) concentrations for $72 \mathrm{~h}$. Values are mean \pm SD of 4 experiments in triplicate (A). Significance of $1 \mathrm{mM}$ L-NAME versus BPH-1 control; ${ }^{* *} \mathrm{p}<0.005$. Significance of $1 \mathrm{mM}$ L-NAME versus LnCap control; " $\mathrm{p}<0.05$. (B) Representative images of BPH-1 and LnCap cells cultured in presence and absence of $1 \mathrm{mM} \mathrm{L-NAME}$ treatment.

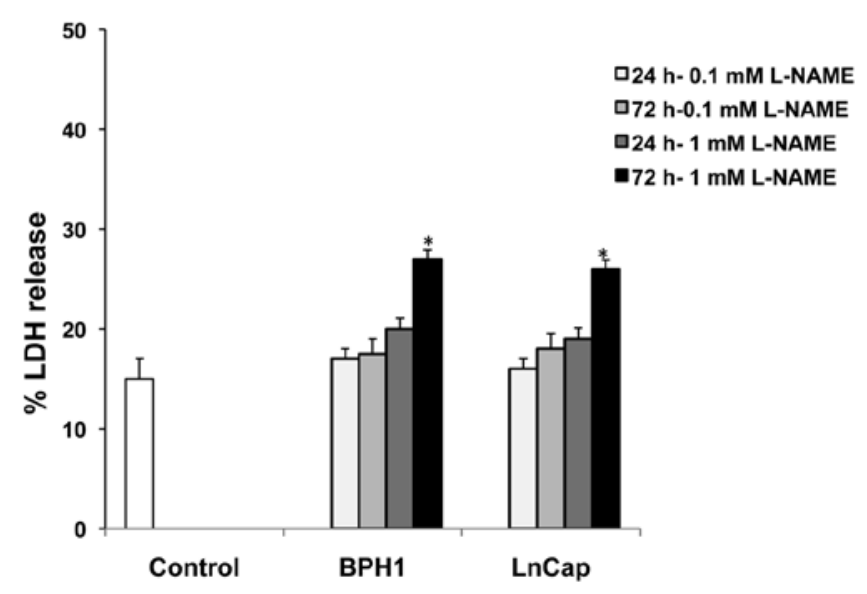

Figure 3. Percentage of LDH released in culture medium of BPH-1 and LnCap cells after treatment with different L-NAME (0.1-1 mM) concentrations for 24 and $72 \mathrm{~h}$. Values are the mean \pm SD of 4 experiments in triplicate.Significance of $1 \mathrm{mM}$ L-NAME versus control; ${ }^{*} \mathrm{p}<0.05$.

Effect of L-NAME on DDAH-2, eNOS, iNOS and VEGF expression in LnCap cells and BPH-1 cells. Higher DDAH-2 expression 


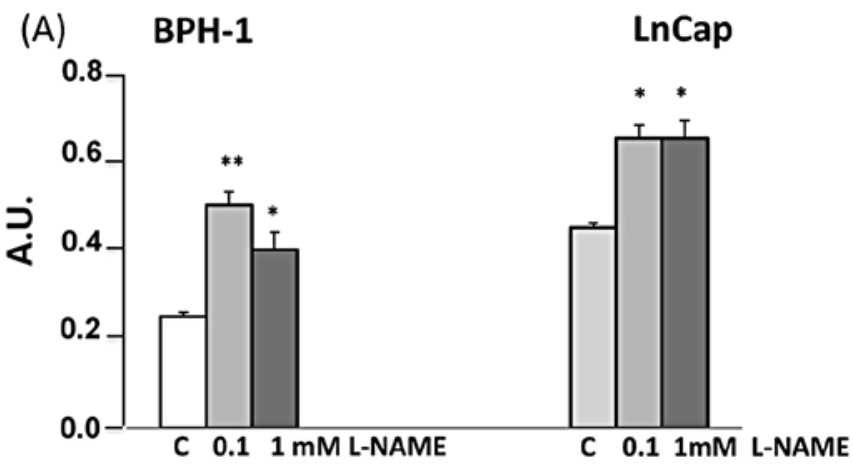

(B)

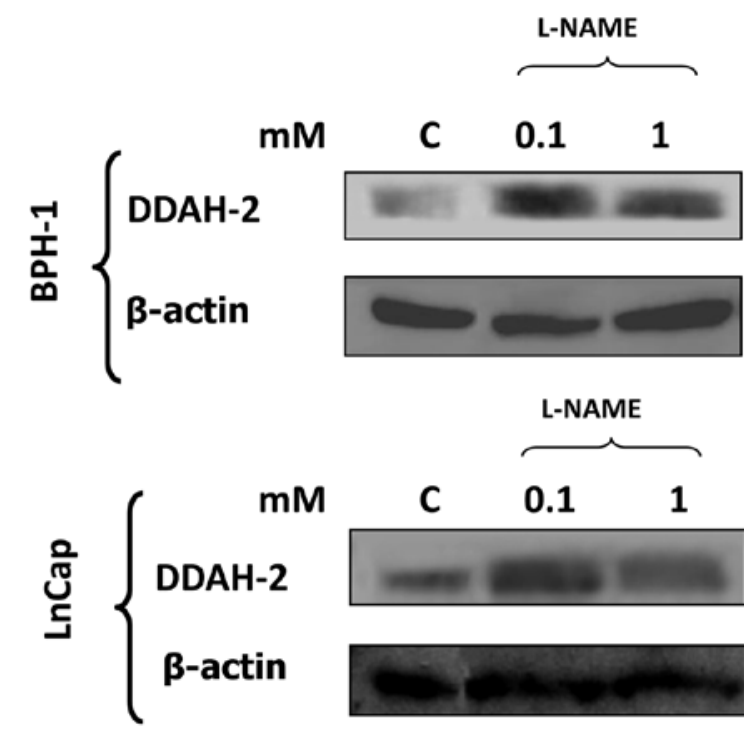

Figure 4. Effect of L-NAME (0.1-1 mM) on DDAH-2 expression in cultured BPH-1 and LnCap cells. Results, expressed as arbitrary units (AU), represent the mean \pm SD of 4 experiments (A). Significance of $0.1 \mathrm{mM}$ L-NAME versus $\mathrm{BPH}-1$ control $(\mathrm{C}) ;{ }^{* *} \mathrm{p}<0.005$. Significance of $1 \mathrm{mM}$ L-NAME versus BPH-1 control and of L-NAME (0.1-1 mM) versus LnCap control (C); ${ }^{*} \mathrm{p}<0.05$. (B) Representative Western blotting of DDAH-2 protein expression in cultured BPH-1 and LnCap cells.

was found in LnCap cells compared to BPH-1 cells. L-NAME treatment resulted in an increase in DDAH-2 in both BPH-1 and LnCap cells. However the effects were different. In BPH-1 $0.1 \mathrm{mM}$ L-NAME increased DDAH-2 expression $(\mathrm{p}<0.005)$ to a greater extent than $1 \mathrm{mM} \mathrm{L-NAME}$. In LnCap cells both 0.1 and $1 \mathrm{mM}$ L-NAME increased DDAH-2 expression to the same extent $(\mathrm{p}<0.05)$ (Fig. 4A). Fig. 4B reports representative Western blotting of DDAH-2 protein expression in cultured BPH-1 and LnCap cells. Higher eNOS expression was found in LnCap cells compared to BPH-1 cells. L-NAME had no effect in eNOS expression in BPH-1 cells. In contrast L-NAME $(0.1$ and $1 \mathrm{mM})$ produced a significant decrease $(\mathrm{p}<0.005)$ in eNOS expression in LnCap cells (Fig. 5A). Fig. 5B reports representative Western blotting of eNOS protein expression in cultured BPH-1 and LnCap cells. Higher iNOS expression was found in LnCap cells compared to BPH-1 cells. L-NAME had no effect in iNOS expression in BPH-1 cells. In contrast L-NAME produced a significant dose-dependent decrease in iNOS expression in LnCap cells (Fig. 6A). Fig. 6B reports representative Western blotting of iNOS protein expression in cultured $\mathrm{BPH}-1$ and

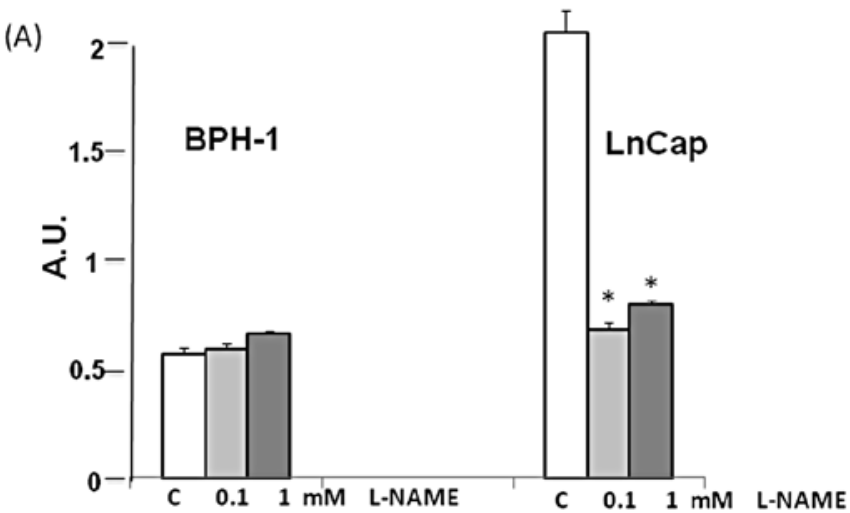

(B)

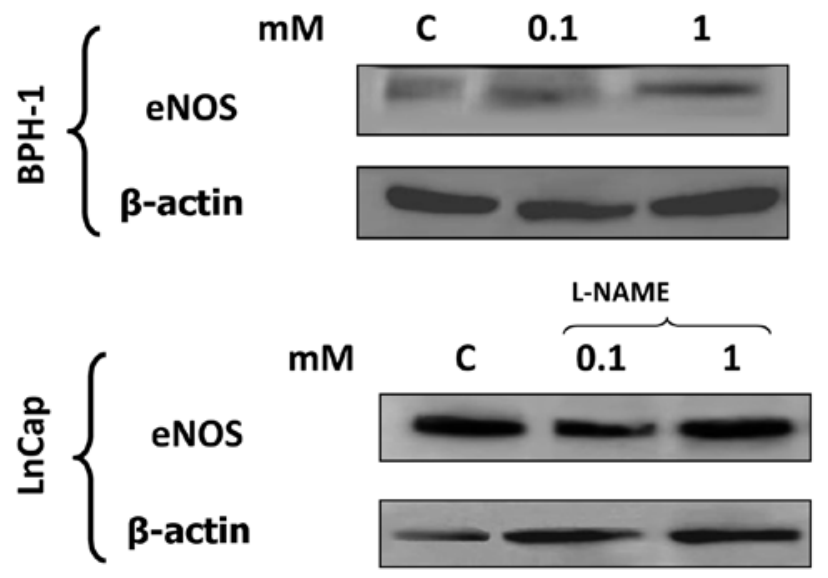

Figure 5. Effect of L-NAME (0.1-1 mM) on eNOS expression in cultured BPH-1 and LnCap cells. Results, expressed as arbitrary units (AU), represent the mean \pm SD of 4 experiments (A). Significance of L-NAME (0.1-1 mM) versus control (C); ${ }^{*}<<0.005$. (B) Representative Western blotting of eNOS protein expression in cultured BPH-1 and LnCap cells.

LnCap cells. Higher VEGF expression was found in LnCap cells compared to BPH-1 cells. L-NAME had no effect on VEGF expression in BPH-1 cells. VEGF expression was unaffected by $0.1 \mathrm{mM}$ L-NAME in Ln Cap cells, however $1 \mathrm{mM}$ L-NAME produced a significant $(\mathrm{p}<0.005)$ decrease in VEGF expression (Fig. 7A). Fig. 7B reports representative Western blotting of VEGF protein expression in cultured BPH-1 and LnCap cells.

Effect of L-NAME on DDAH activity. L-NAME resulted in a significant $(\mathrm{p}<0.05)$ increase in DDAH activity at both 0.1 and $1 \mathrm{mM}$ L-NAME in BPH-1 cells. Control levels of DDAH activity were higher in LnCap cells when compared to BPH-1 cells. L-NAME resulted in a dose-dependent increase in DDAH activity $(\mathrm{p}<0.005)$ when compared to control in LnCap cells (Fig. 8).

Effect of L-NAME on nitrite/nitrate levels. The effect of both concentrations, 0.1 and $1 \mathrm{mM}$, of L-NAME was examined in BPH-1 and LnCap cells. The dose of $0.1 \mathrm{mM}$ L-NAME had no effect on nitrite/nitrate levels in either cell line. In contrast, $1 \mathrm{mM}$ L-NAME caused a significant $(\mathrm{p}<0.05)$ decrease in nitrite/nitrate levels in both cell lines (Table I). 
(A)

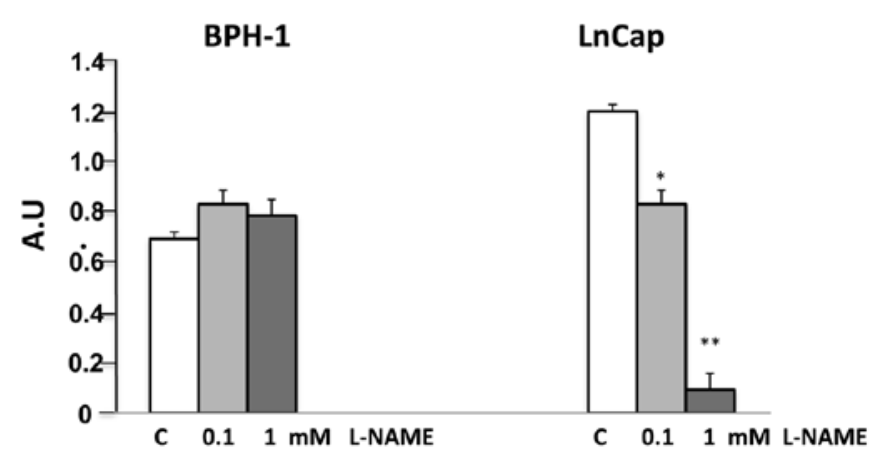

(B)

\section{L-NAME}

$$
\text { 곰 }\left\{\begin{array}{r}
\mathrm{mM} \\
\text { iNOS } \\
\beta \text {-actin }
\end{array}\right.
$$

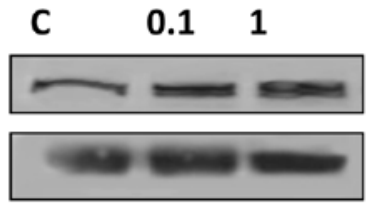

L-NAME

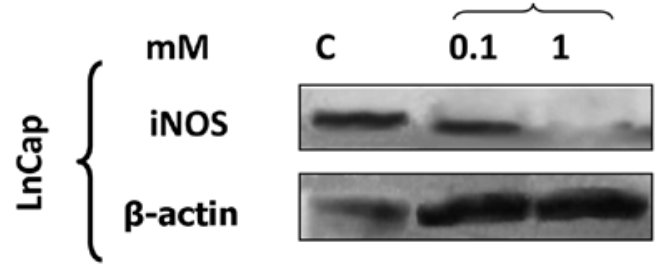

Figure 6. Effect of L-NAME (0.1-1 mM) on iNOS expression in cultured BPH-1 and LnCap cells. Results, expressed as arbitrary units (AU), represent the mean \pm SD of 4 experiments (A). Significance of L-NAME $(0.1 \mathrm{mM})$ versus control (C); ${ }^{*} \mathrm{p}<0.05$. Significance of L-NAME $(1 \mathrm{mM})$ versus control $(\mathrm{C}) ;{ }^{* *} \mathrm{p}<0.005$. (B) Representative Western blotting of iNOS protein expression in cultured BPH-1 and LnCap cells.

Table I. Nitrite/nitrate levels in BPH-1 and LnCap cells.

\begin{tabular}{lcc}
\hline & Nitrite/nitrate & nmoles $/ 1 \times 10^{6}$ cells \\
\hline BPH-1 & Control & $25.26 \pm 0.5$ \\
& L-NAME 0.1 mM & $24.66 \pm 0.7$ \\
& L-NAME $1 \mathrm{mM}$ & $18.07 \pm 0.3^{\mathrm{a}}$ \\
LnCap & Control & $38.25 \pm 1.9$ \\
& L-NAME 0.1 mM & $37.65 \pm 1.3$ \\
& L-NAME $1 \mathrm{mM}$ & $21.66 \pm 1.1^{\mathrm{a}}$ \\
\hline
\end{tabular}

Results represent the mean \pm SD of four experiments. Significance of $1 \mathrm{mM}$ L-NAME versus control. ${ }^{\mathrm{a}} \mathrm{p}<0.05$.

\section{Discussion}

Angiogenesis is a multi-step process that may be considered a major factor affecting the metastatic spread of malignant cells $(50,51)$. Investigations published on experimental tumor models and on several types of human tumor including gynecologic, head and neck, breast, central nervous system, colorectal and

(A)

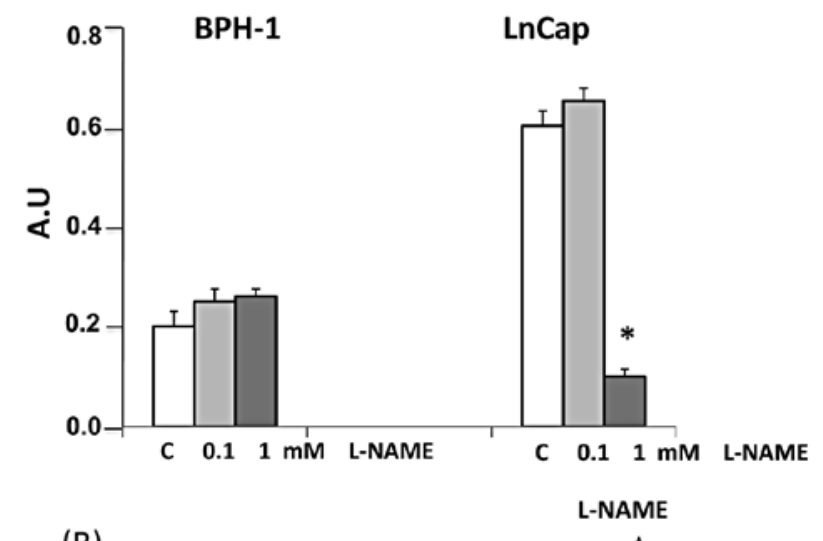

(B)
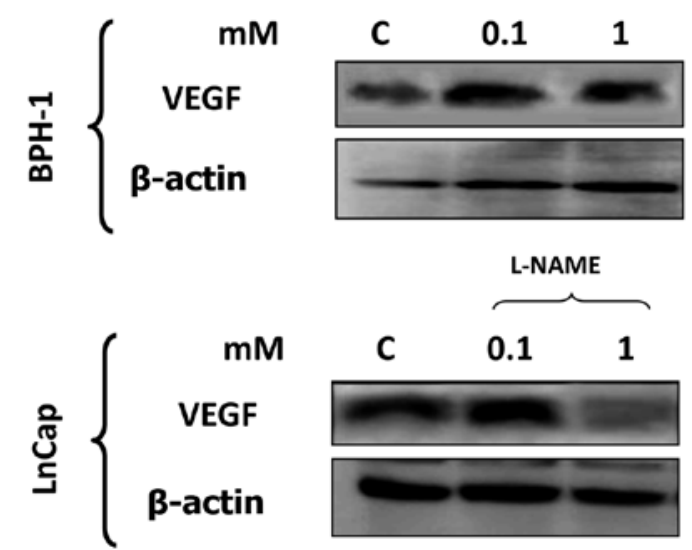

Figure 7. Effect of L-NAME (0.1-1 mM) on VEGF expression in cultured BPH-1 and LnCap cells. Results, expressed as arbitrary units (AU), represent the mean \pm SD of 4 experiments (A). Significance of L-NAME (1 mM) versus control (C); " $\mathrm{p}<0.005$. (B) Representative Western blotting of VEGF protein expression in cultured BPH-1 and LnCap cells.

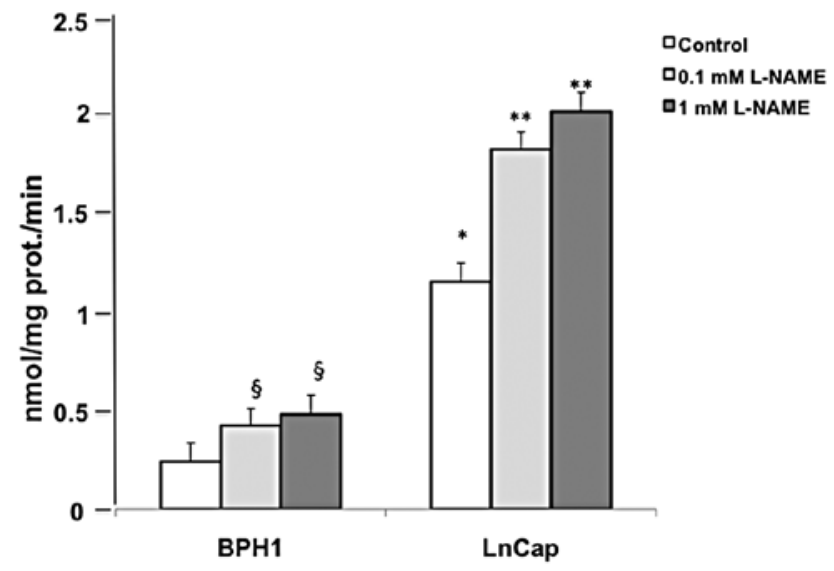

Figure 8. Effect of different L-NAME (0.1-1 mM) concentrations on DDAH activity in cell lysates. Enzymatic activity was determined by measuring $\mathrm{L}$-citrulline formation and expressed as nmoles $/ \mathrm{mg}$ of protein/min. Results represent the mean \pm SD of 4 experiments. Significance of LnCap control versus BPH-1 control: " $\mathrm{p}<0.005$. Significance of L-NAME $(0.1-1 \mathrm{mM})$ versus BPH-1 control; ${ }^{\S} \mathrm{p}<0.05$. Significance of L-NAME $(0.1-1 \mathrm{mM})$ versus LnCap control; ${ }^{* *} \mathrm{p}<0.005$.

prostate cancer $(32,33,35,39,52-58)$ have shown an increased expression of iNOS. Such overexpression has been correlated to 


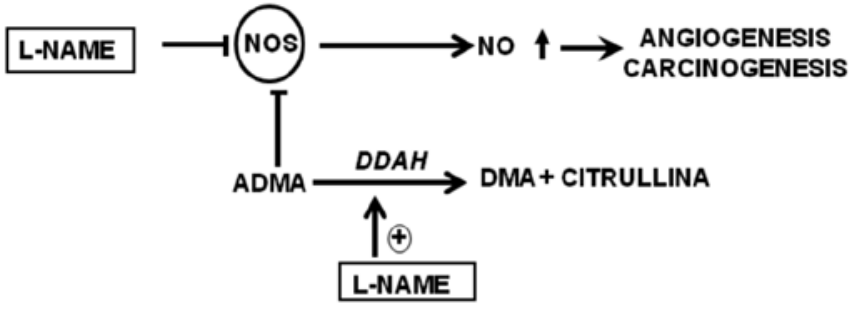

Figure 9. DDAH/NOS pathway: effect of NOS inhibitor L-NAME.

tumor progression. In addition eNOS overexpression has been reported in various type of cancer including prostate cancer (37,59-64). NO produced by eNOS may be involved in tumor angiogenesis. On the other hand, it has been shown that in the absence of eNOS tumor cells became more dependent on iNOSderived $\mathrm{NO}$ for survival and tumor angiogenesis (65). Therefore, NO produced by iNOS may contribute to tumor angiogenesis. The significant decrease in BPH-1 and LnCap cell number with $1 \mathrm{mM}$ L-NAME treatment that we report, is in agreement with increased LDH release. We show that cell survival was decreased after L-NAME treatment under our experimental conditions. However, tumoral LnCap cells are more resistant to treatment when compared to BPH1 cells. Moreover, the reduction in BPH-1 cell survival induced by L-NAME may represent a preventive strategy because patients with BPH would be stratified as cases at higher risk of carcinogenic development in the prostate (66).

The increased iNOS and eNOS expression that we report, support the hypothesis that NOS overexpression in prostatic cancer cells, as in numerous other cancer cell lines, may be correlated with tumor progression and metastasis $(30-35,37,39,54,62,67)$. In addition, increased eNOS, iNOS and VEGF expressions, could contribute to tumor progression by enhancing tumor vascularization $(65,68,69)$. The resistance of LnCap cells to L-NAME treatment may be related to iNOS and eNOS overexpression, in fact iNOS and eNOS overexpression has been correlated with aggressive tumor phenotype and poor prognosis $(55,70)$. Moreover, results obtained in the present study suggest that also in prostate cancer, as in cerebral tumors (41), increased expression and activity of DDAH-2 may contribute to stimulating tumor growth and angiogenesis through increased NO formation.

Targeting angiogenesis in the therapeutic intervention of cancer has received substantial attention. In particular, therapeutic interventions using molecules that may modulate the DDAH/NOS pathway are plausible. NOS inhibitors have been suggested as antitumor therapeutics $(52,65,69,71-81)$. However, the antitumor and antimetastatic effects of NOS inhibitors may be attributed in part to reduced tumor cell invasiveness $(52,72,73,78,81)$ and in part to reduced neovascularization $(69,71,74,75,77,79)$. The importance of the DDAH/NOS pathway in the angiogenic process is confirmed by treatment with the NOS inhibitor L-NAME, which, under our experimental conditions, resulted in a reduction, not only in iNOS and eNOS activity, but also in VEGF, iNOS and eNOS expression. These effects may explain a possible antiangiogenic effect of L-NAME $(82,83)$ and are in agreement with studies that show angiogenesis inhibition in DDAH-TG mice by exogenous L-NAME (40).
The increased DDAH-2 expression and activity reported after L-NAME treatment, both of BPH-1 and LnCap cells, may represent an adaptational response to the presence of L-NAME (an inhibitor that is not degraded by DDAH) by reducing endogenous ADMA levels. iNOS and eNOS inhibition is a promising approach for targeting tumor vasculature and certain NOS inhibitors potentially serve as experimental agents for treatment of certain chemoresistant tumors, including prostate tumors (Fig. 9). Moreover, since L-NAME was unable to reduce DDAH activity and expression, as reported by Wang et al (84), it is plausible to hypothesize the development of a targeted polypharmacological approach by developing dual and specific inhibitors of DDAH and NOS to better control NO biosynthesis.

\section{References}

1. Ferlay J, Parkin DM and Steliarova-Foucher E: Estimates of cancer incidence and mortality in Europe in 2008. Eur J Cancer 46: 765-781, 2010.

2. Drzymalski DM, Oh WK, Werner L, Regan MM, Kantoff P and Tuli S: Predictors of survival in patients with prostate cancer and spinal metastasis. J Neurosurg Spine 13: 789-794, 2010.

3. Nayyar R, Sharma N and Gupta NP: Prognostic factors affecting progression and survival in metastatic prostate cancer. Urol Int 84: 159-163, 2010.

4. Yigitbasi O, Ozturk U, Goktug HN, Gucuk A and Bakirtas H: Prognostic factors in metastatic prostate cancer. Urol Oncol 29: 162-165, 2011.

5. Folkman J: How is blood vessel growth regulated in normal and neoplastic tissue? G.H.A. Clowes Memorial Award Lecture. Cancer Res 46: 467-473, 1986.

6. Folkman J, Watson K, Ingber D and Hanahan D: Induction of angiogenesis during the transition from hyperplasia to neoplasia. Nature 339: 58-56, 1989.

7. Liotta LA, Steeg PS and Stetler-Stevenson WG: Cancer metastasis and angiogenesis: an imbalance of positive and negative regulation. Cell 64: 327-336, 1999.

8. Fidler IJ and Ellis LM: The implications of angiogenesis for the biology and therapy of cancer metastasis. Cell 79: 185-188, 1994.

9. Folkman J: Clinical applications of research on angiogenesis. N Engl J Med 333: 1757-1763, 1995.

10. Hanahan D and Weinberg RA: The hallmarks of cancer. Cell 100: 57-70, 2000.

11. Folkman J: What is the evidence that tumors are angiogenesis dependent? J Nat Cancer Inst 82: 4-6, 1990.

12. Ferrara $\mathrm{N}$ and Kerbel RS: Angiogenesis as a therapeutic target. Nature 438: 967-974, 2005.

13. Fox SB, Leek RD, Weekes MP, Whitehouse RM, Gatter KC and Harris AL: Quantitation and prognostic value of breast cancer angiogenesis: comparison of microvascular density. Chalkeley count, and computer image analysis. J Pathol 177: 275-283, 1995.

14. Weidner N, Carroll P, Flax J, Blumenfeld W and Folkman J: Tumour angiogenesis: correlation with metastases in invasive prostate carcinoma. Am J Pathol 143: 401-409, 1993.

15. Brustman $H$, Riss $P$ and Naude $S$ : The relevance of angiogenesis in benign and malignant epithelial tumours of the ovary: a quantitative histological study. Gynecol Oncol 67: 20-26, 1997.

16. Hanahan D and Folkman J: Patterns and emerging mechanisms of the angiogenic switch during tumorigenesis. Cell 86: 353-364, 1996.

17. Folkman J: Angiogenesis in cancer, vascular, rheumatoid and other disease. Nat Med 1: 23-31, 1995.

18. Moncada S, Palmer RMJ and Higgs EA: Nitric oxide: physiology, pathology and pharmacology. Pharm Rev 43: 109-142, 1991.

19. Xu W, Liu LZ, Loizidou M, Ahmed M and Charles IG: The role of nitric oxide in cancer. Cell Res 2: 311-320, 2002.

20. Chinje EC and Stratford IJ: Role of nitric oxide in growth of solid tumours: a balancing act. Essays Biochem 32: 61-72, 1997.

21. Griffioen AW and Molema G: Angiogenesis: potentials or pharmacologic intervention in the treatment of cancer, cardiovascular disease and crhonic inflammation. Pharm Rev 52: 237-268, 2000 . 
22. Ziche M, Morbidelli L, Masini E, Amerini S, Granger HJ, Maggi CA, Geppetti P and Ledda F: Nitric oxide mediates angiogenesis in vivo and endothelial cell growth and migration in vitro promoted by substance. PJ Clin Invest 94: 2036-2044, 1994.

23. Trachtman H, Futterweit S, Garg P, Reddy K and Singhal PC: Nitric oxide stimulates the activity of a $72-\mathrm{kDa}$ neutral matrix metalloproteinase in cultured rat mesengial cells. Biochem Biophys Res Commun 218: 704-708, 1996.

24. Fukumura D, Yuan F, Endo M and Jain RK: Role of nitric oxide in tumor microcirculation. Blood flow, vascular permeability, and leukocyte-endothelial interactions. Am J Pathol 150: 713-725, 1997.

25. Chin K, Kurashima Y, Ogura T, Tajiri H, Yoshida S and Esumi H Induction of vascular endothelial growth factor by nitric oxide in human glioblastoma and hepatocellular carcinoma cells. Oncogene 15: 437-442, 1997

26. Papapetropoulos A, Garcia-Cardena G, Madri JA and Sessa WC: Nitric oxide production contributes to the angiogenic properties of vascular endothelial growth factorin human endothelial cell. J Clin Invest 100: 3131-3139, 1997.

27. Sciarra A, Mariotti G, Salciccia S. Gomez AA, Monti S, Toscano V and Di Silverio F: Prostate growth and inflammation. J Steroid Biochem Mol Biol 108: 254-260, 2008.

28. Aydin A, Arsofa-Sarafinovska Z, Sayal A, Eken A, Erdem O, Erten K, Ozgok Y and Dimovski A: Oxidative stress and antioxidant in non-metastatatic prostate cancer and benign prostatec hyperplasia. Clin Biochem 39: 176-179, 2006.

29. Jung K, Seidel B, Rudolph B, Lein M, Cronauver MV, Henke W, Hampel G, Schnorr D and Loening SA: Antioxidant enzymes in malignant cell lines and in primary cultured prostatic cells. Free Radical Biol Med 23: 127-133, 2007.

30. Thomsen LL, Lawton FG, Knowles RG, Beesley JE, RiverosMoreno V and Moncada S: Nitric oxide synthase activity in human gynecological cancer. Cancer Res 54: 1352- 1354, 1994.

31. Thomsen LL, Miles DW, Happerfield L, Bobrow LG, Knowles RG and Moncada S: Nitric oxide synthase activity in human breast cancer. Br J Cancer 72: 41-44, 1995.

32. Duenas-Gonzalez A, Isales CM, del Mar Abad-Hernadez M, Gonzalez-Sarmiento R, Sangueza O and Rodriguez-Commes J: Expression of inducible nitric oxide synthase in breast cancer correlates with metastatic disease. Mol Pathol 10: 645-649, 1997.

33. Cobbs CS, Brenman JE, Aldape KD, Bredt DS and Israel MA: Expression of nitric oxide synthase in human central nervous system tumors. Cancer Res 55: 727-730, 1995.

34. Thomsen LL and Miles DW: Role of nitric oxide in tumor progression: lessons from human tumors. Cancer Metastasis Rev 17: 107-118, 1998

35. Klots T, Bloch W, Volberg C, Engelmann U and Addicks K: Selective expression of inducible nitric oxide synthase in human prostate carcinoma. Cancer 82: 1897-1903, 1998

36. Chen GG, Lee TW, Xu H, Yip JH, Li M, Mok TS and Yim AP Increased inducible nitric oxide synthase in lung carcinoma of smokers. Cancer 112: 372-381, 2008.

37. Lukes $\mathrm{P}$, Pàcovà $\mathrm{H}$, Kucera $\mathrm{T}$, Vesely $\mathrm{D}$, Martinek $\mathrm{J}$ and Asti $\mathrm{J}$ : Expression of endothelial and inducible nitric oxide synthase and caspase-3 in tonsillar cancer, chronic tonsillitis and healthy tonsils. Folia Biol 54: 141-145, 2008.

38. Brennan PA, Palacios-Callender M, Zaki GA, Spedding AV and Langdon JD: Type II nitric oxide synthase $\left(\mathrm{NOS}_{2}\right)$ expression correlates with lynphnode status in oral squamous carcinoma. J Oral Pathol Med 30: 129-134, 2001.

39. Gallo O, Masini E, Morbidelli L, Franchi A, Fini-Storchi I, Vergari WA and Ziche M: Role of nitric oxide in angiogenesis and tumor progression in head and neck cancer. J Natl Cancer Inst 90: 587-596, 1998.

40. Jacobi J, Sydow K, von Degenfeld G, Zhang Y, Dayoub H, Wang B, Patterson AJ, Kimoto M, Blau HM and Cooke JP: Overexpression of dimethyl arginine dimethylamino hydrolase reduces tissue asymmetric dimethylarginine levels and enhances angiogenesis. Circulation 22: 1431-1438, 2005

41. Kostourou V, Robinson SP, Cartwright JE and Whitley GS: Dimethylarginine dimethylaminohydrolase I enhances tumour growth and angiogenesis. Br J Cancer 87: 673-680, 2002.

42. Leiper J, Santa Maria J, Chubb A, MacAllister RJ, Charles I, Whithley GSJ and Vallance P: Identification of two human dimethylarginine dimethylaminohydrolases with distinct tissue distributions and homology to microbial arginine deiminases, Biochem J 343: 209-214, 1999.
43. Tran CT, Fox MF, Vallance P and Leiper JM: Chromosomal localization, gene structure, and expression pattern of DDAH1: comparison with DDAH2 and implications for evolutionary origins. Genomics 68: 101-105, 2000 .

44. Horoszewicz JS, Leong SS, Kawinski E, Karr JP, Rosenthal H, Chu TM, Mirand EA and Murphy GP: LnCap model of human prostatic carcinoma. Cancer Res 43: 1809-1818, 1983.

45. Hayward SW, Dahiya R, Cunha G R, Bartek J, Deshpande N and Narayan P: Establishment and characterization of an immortalized but non-transformed human prostate epithelial cell line: BPH1. In Vitro Cell Dev Biol 31A: 14-24, 1995.

46. Pavone A and Cardile V: An in vitro study of new antiepileptic drugs and astrocytes. Epilepsia 44 (Suppl 10): 34-39, 2003.

47. Renis M, Cardile V, Grasso S, Palumbo M and Scifo C: Switching off HSP70 and i-NOS to study their role in normal and $\mathrm{H}_{2} \mathrm{O}_{2}$ stressed human fibroblasts. Life Sci 74: 757-769, 2003.

48. Lowry OH, Rosenbrough NJ, Farr AJ and Randall RG: Protein measurement with the Folin phenol reagent. J Biol Chem 193: 265-275,1951

49. Knipp M and Vasak M: A colorimetric 96-well microtirer plate assay for the determination of enzymatically formed citrulline. Anal Biochem 286: 257-264, 2000.

50. Liekens S, De Clercq E and Neyts J: Angiogenesis: regulators and clinical application. Biochem Pharmacol 61: 253-270, 2000.

51. Tanigawa N, Amaya H, Matsumura M, Lu C, Kitaoka A and Matsuyama K: Tumor angiogenesis and mode of metastasis in patients with colorectal cancer. Cancer Res 57: 1043-1046, 1997.

52. Orucevic A, Bechberger J, Green A M, Shapiro RA, Billiar TR and Lala PK: Nitric-oxide production by murine mammary adenocarcinoma cells promotes tumor-cell invasiveness. Int J Cancer 81: 889-896, 1999.

53. Svec J, Ergang P, Mandys V, Kment M and Pácha J: Expression profiles of proliferative and antiapoptotic genes in sporadic and colitis-related mouse colon cancer models. Int J Exp Pathol 91: 44-53, 2010.

54. Saed GM, Ali-Fehmi R, Jiang ZL, Fletcher NM, Diamond MP, Abu-Soud HM and Munkarah MR: Myeloperoxidase serves as a redox switch that regulates apoptosis in epithelial ovarian cancer. Gynecol Oncol 116: 276-281, 2010.

55. Lecuru F, Metzeger U,Levy E, Lefreree-Belda MA and Bensaid C: Ovarian cancer: diagnosis of early stages, referral of patients and management. Rev Prat 54: 1763-1769, 2004.

56. Wang YZ, Cao YQ, Wu JN, Chen M and Cha XY: Expression of nitric oxide synthase in human gastric carcinoma and its relation to p53, PCNA. World J Gastroenterol 11: 46-50, 2005.

57. Peng JP, Zheng S, Xiao ZX and Zhang SZ: Inducible nitric oxide synthase expression is related to angiogenesis, bcl-2, and cell proliferation in hepatocellular carcinoma. J Zhejiang Univ Sci 4: 221-227, 2003

58. Narayanan BA, Narayanan NK, Simi B and Reddy BS: Modulation of indicible nitric oxide synthase and related proinflammatory genes by the omega-3 fatty acid docosahexaenoic acid in human colon cancer cells. Cancer Res 63: 972-979, 2003.

59. Lim KH, Ancrile BB, Kashatus DF and Counter CM: Tumour maintenance is mediatedby eNOS. Nature 452: 646-649, 2008.

60. Fukumura D, Kashiwagi S and Jain RK: The role of nitric oxide in tumor progression. Nat Rev Cancer 6: 521-534, 2006.

61. Ying L and Hofseth LJ: An emerging role for endothelial nitric oxide synthase in chronic inflammation and cancer. Cancer Res 67: 1407-1410, 2007

62. Polytarchou C, Hatziapostolou M, Poimenidi E, Papadopoulou A, Parthymou A and Papadimitriou E: Nitric oxide stimulates migration of human endothelial and prostate cancer cells through up-regulation of pleiotrophin expression and its receptor protein tyrosine phosphate beta/zeta. Int J Cancer 124: 1785-1793, 2009.

63. Shang ZJ and Li JR: Expression of endothelial nitric oxide synthase and vascular endothelial growth factor in oral squamous cell carcinoma: its correlation with angiogenesis and disease progression. J Oral Pathol Med 34: 134-139, 2005.

64. Bentz BG, Haines GK, Lingen MW, Pelzer HJ, Hanson DG and Radosevich JA: Nitric oxide synthase type 3 is increased in squamous hyperplasia, dysplasia, and squamous cell carcinoma of the head and neck. Am Otol Rhinol Laryngol 108: 781-787, 1999.

65. Chen G, Qian HS, Liu P, Brooks A, Rubanyi GM and Kauser K: i-NOS derived NO substitutes for endothelial NO in tumor angiogenesis and tumor growth in the absence of ecNOS expression. Nitric Oxide 14: A16, 2006. 
66. Hamid ARAH, Umbas R and Mochtar CA: Recent role of inflammation in prostate diseases: chemoprevention development opportunity: Acta Med Indones-Indones. J Intern Med 43: 59-65, 2011.

67. Fujmoto H, Ando Y, Yamashita T, Terazaki H, Tanaka Y, Sasaki J, Matsumoto M. Suga, M and Ando M: Nitric oxide synthase activity in human lung cancer. Jpn J Cancer Inst 88: $1190-1198,1997$.

68. Fukumura D, Gohongi T, Kadambi A, Izumi Y, Ang J, Yun CO, Buerk Huang DJ and Jain RK: Predominant role of endothelial nitric oxide synthase in vascular endothelial growth factor-induced angiogenesis and vascular permeability. Proc Natl Acad Sci USA 98: 2604-2609, 2001

69. Malone JM, Saed GM, Diamond MP, Sokol RJ and Munkaraha AR: The effects of the inhibition of inducible nitric oxide synthase on angiogenesis of epithelial ovarian cancer. Am J Obstet Gynecol 194: 1110-1118, 2006.

70. Nanni S, Benvenuti V, Grasselli A, Priolo C, Aiello A, Mattiussi S, Colussi C, Lirangi V, Illi B, D'Eletto M, Cianciulli AM, Gallucci M, De Carli P, Sentinelli S, Mottolese M, Carlini P, Strigari L, Finn S, Mueller E, Arcangeli G, Gaetano C, Capogrossi MC, Donnorso RP, Bacchetti S, Sacchi A, Pontecorvi A, Loda M and Farsetti A: Endothelial NOS, estrogen receptor $\beta$, and HIFs cooperate in the activation of a prognostic transcriptional pattern in aggressive human prostate cancer. J Clin Invest 119: 1093-1108, 2009.

71. Tozer GM, Prise VE, Lewis G, Xie S, Wilson I and Hill SA: Nitric oxide synthase inhibition enhances the tumor vascular-damaging effects ocombretastatin a-4 3-o-phosphate at clinically relevant doses. Clin Cancer Res 15: 3781-3790, 2009.

72. Punathil T, Tollefsbol TO and Katiyar SK: EGCG inhibits mammary cancer cell migration through inhibition of nitric oxide synthase and guanylate cyclase. Biochem Biophys Res Commun 375: 162-167, 2008

73. Yu LB, Dong XS, Sun WZ, Zhao DL and Yang Y: Effect of a nitric oxide synthase inhibitor NG-nitro-L-arginine methyl ester on invasion of human colorectal cancer cell line SL-174T. World J Gastroenterol 11: 6385-6388, 2005.

74. Kon K, Fujii S, Kosaka H and Fujiwara T: Nitric oxide synthase inhibition by $\mathrm{N}(\mathrm{G})$-nitro-L-arginine methyl ester retards vascular sprouting in angiogenesis. Microvasc Res 65: 2-8, 2003.

75. Camp ER, Yang A, Liu W, Fan F, Somcio R, Hicklin DJ and Ellis LM: Roles of nitric oxide synthase inhibition and vascular endothelial growth factor receptor-2 inhibition on vascular morphology and function in an in vivo model of pancreatic cancer. Clin Cancer Res 12: 2628-2633, 2006.
76. Pullen NA and Fillmore HL: Induction of matrix metalloproteinase-1 and glioma cell motility by nitric oxide. J Neurooncol 96: 201-209, 2010.

77. Uneda S, Hata H, Matsuno F, Nagasaki A, Harada N, Mitsuya Y, Matsuzaki $\mathrm{H}$ and Mitsuya $\mathrm{H}$ : A nitric oxide synthase inhibitor, $\mathrm{N}(\mathrm{G})$-nitro-l-arginine-methyl-ester, exerts potent antiangiogenic effects on plasmacy toma in a newly established multiple myeloma severe combined immunodeficient mouse model. $\mathrm{Br}$ J Haematol 120: 396-404, 2003.

78. Punathil T and Katiyar SK: Inhibition of non-small cell lung cancer cell migration by grape seed proanthocyanidins is mediated through the inhibition of nitric oxide, guanylate cyclase, and ERK1/2. Mol Carcinog 48: 232-242, 2009.

79. Thejass P and Kuttan G: Allyl isothiocyanate (AITC) and phenyl isothiocyanate (PITC) inhibit tumour-specific angiogenesis by downregulating nitric oxide (NO) and tumour necrosis factoralpha (TNF-alpha) production. Nitric Oxide 16: 247-257, 2007.

80. Fitzpatrick B, Mehibel M, Cowen RL and Stratford IJ: iNOS as a therapeutic target for treatment of human tumors. Nitric Oxide 19: $217-224,2008$.

81. Ohtsu N, Takaoka K, Segawa E, Hashitani S, Noguchi K, Kishimoto $\mathrm{H}$ and Urade M: Antitumor effects of inhibitors of nitric oxide synthase or cyclooxygenase- 2 on human KB carcinoma cells overexpressing COX-2. Oncol Rep 24: 31-36, 2010.

82. Jadeski LC and Lala PK: Nitric oxide synthase inhibition by NG-Nitro-L-Arginine methyl ester inhibits tumor induced angiogenesis in mammary tumors. Am J Pathol 155: 1381-1390, 1999.

83. Davel L, Eijan AM, Sales ME, Espanol A, D'Agostino A, Piccardo I, Lauria L, De Lustig ES and Jasnis MA: Reactivity of tumor-draining lymph nodes and the nitric oxide pathway. Int $\mathbf{J}$ Oncol 20: 59-67, 2002.

84. Wang Y, Monzingo AF, Hu S, Schaller TH, Robertus JD and Fast W: Developing dual and specific inhibitors of dimethylarginine dimethylaminohydrolase-1 and nitric oxide synthase: toward a targeted polypharmacology to control nitric oxide. Biochemistry 48: 8624-8635, 2009 